\title{
Determination of Heavy Metals in Hibiscus cannabinus and Moringa oleifera Cultivated at Zango Abattoir, Tudun Wada, Kaduna Metropolis
}

\author{
Yarima Muhammad Malum*, Labaran Salihu \\ Department of Chemistry, Nigerian Defence Academy, Kaduna, Nigeria \\ Email address: \\ yarimaimam@yahoo.com (Y. M. Malum), labsal2002@yahoo.com (L. Salihu) \\ ${ }^{*}$ Corresponding author
}

\section{To cite this article:}

Yarima Muhammad Malum, Labaran Salihu. Determination of Heavy Metals in Hibiscus cannabinus and Moringa oleifera Cultivated at Zango Abattoir, Tudun Wada, Kaduna Metropolis. International Journal of Sustainable Development Research.

Vol. 3, No. 4, 2017, pp. 32-35. doi: 10.11648/j.ijsdr.20170304.11

Received: August 19, 2017; Accepted: August 30, 2017; Published: October 7, 2017

\begin{abstract}
This study was carried out to determine and evaluate the concentration of ten heavy metals $(\mathrm{As}, \mathrm{Cd}, \mathrm{Co}, \mathrm{Cr}, \mathrm{Cu}$, $\mathrm{Fe}, \mathrm{Pb}, \mathrm{Mn}, \mathrm{Ni}$ and $\mathrm{Zn}$ ) in Hibiscus cannabinus and Moringa oleifera grown at Zango Abattoir, Tudun Wada, Kaduna Metropolis Nigeria, using Atomic Absorption Spectrophotometer. The concentration of the metals obtained ranged from $0.628 \pm 0.0006$ to $3.469 \pm 0.0006 \mathrm{mg} / \mathrm{kg}$ for manganese, $8.362 \pm 0.0006$ to $29.293 \pm 0.0026 \mathrm{mg} / \mathrm{kg}$ for iron, $0.700 \pm 0.0002$ to $10.774 \pm 0.0026 \mathrm{mg} / \mathrm{kg}$ for zinc, $0.071 \pm 0.0002$ to $0.223 \pm 0.0005 \mathrm{mg} / \mathrm{kg}$ for copper, $0.020 \pm 0.0006$ to $0.044 \pm 0.0002 \mathrm{mg} / \mathrm{kg}$ for nickel, $0.017 \pm 0.0001$ to $0.039 \pm 0.0001 \mathrm{mg} / \mathrm{kg}$ for cadmium, ND to $0.184 \pm 0.0004 \mathrm{mg} / \mathrm{kg}$ for chromium, $1.092 \pm 0.0003$ to $1.167 \pm 0.0006 \mathrm{mg} / \mathrm{kg}$ for lead and $0.115 \pm 0.0010$ to $0.201 \pm 0.0016 \mathrm{mg} / \mathrm{kg}$ for cobalt. Arsenic was however not detected in all the samples analysed. The concentrations of heavy metals in the selected samples were statistically significant at $(\mathrm{P}<0.05)$. This study highlights that people consuming the vegetables grown within the abattoir consume substantial amount of metals like iron, zinc and lead. However, the values of these metals were below the recommended maximum tolerable guidelines level proposed by the $\mathrm{WHO} / \mathrm{FAO}$ and NAFDAC.
\end{abstract}

Keywords: Abattoir, Hibiscus cannabinus, Moringa oleifera, Heavy Metals, Kaduna

\section{Introduction}

In many parts of the world, human activities such as animal production and meat processing impact negatively on soil and natural water composition. This leads to pollution of such soils, natural water resources and the entire environment [1]. Meat processing is usually carried out in a specialized environment known as abattoir or slaughter house. An abattoir is a place or building where animals are killed for their meat [2]. Abattoir effluent has a complex composition and can be very harmful to the environment. It has also been reported that abattoir activities were responsible for the pollution of soil, surface and ground waters [3-4]. Wastewater from abattoir constitutes one of the greatest threats to environmental safety probably because of the presence of mineral constituents [5]. It contains varying amounts of heavy metals many of which pose serious threat to plants and the ecosystem. Leafy vegetables such as spinach, bitter leaves and horseradish tree leaves and root absorb some of these heavy metals when they are irrigated with abattoir effluent or through runoffs from the field and when in turn consumed by man adversely affects health [6].

The consumption of heavy metal contaminated vegetables constitutes risks to both humans and animals [7]. Vegetables can become contaminated with heavy metals when grown on soils contaminated by abattoir waste and those of other agricultural activities [8-9]. Heavy metal poisoning is the accumulation of heavy metals, in toxic amounts, in the soft tissues of the body. Symptoms and physical findings associated with heavy metal poisoning vary according to the metal accumulated. Many of the heavy metals, such as zinc, copper, chromium, iron and manganese, are essential to body function in very small amounts. But, if these metals accumulate in the body in concentrations sufficient to cause poisoning, then serious damage may occur. The heavy metals most commonly associated with poisoning of humans are 
lead, mercury, arsenic and cadmium [10]. Abattoir effluents contain heavy metals from animal wastes and/or runoff water and these effluents are mainly used for irrigation of plant grown within the abattoir. These plants absorb the metals and are subsequently consumed by human leading to the accumulation of the metals in the human systems. This study is therefore aimed at determining the concentration of heavy metals in Hibiscus cannabinus and Moringa oleifera cultivated within the abattoir.

\section{Materials and Methods}

Fresh Samples of Hibiscus cannabinus and Moringa oleifera were collected at farmlands located in Zango abattoir at Tudun Wada in Kaduna South Local Government area of Kaduna State (Figure 1). The samples were then authenticated in the Herbarium section, Department of Biological Sciences, Ahmadu Bello University Zaria and voucher numbers were issued.

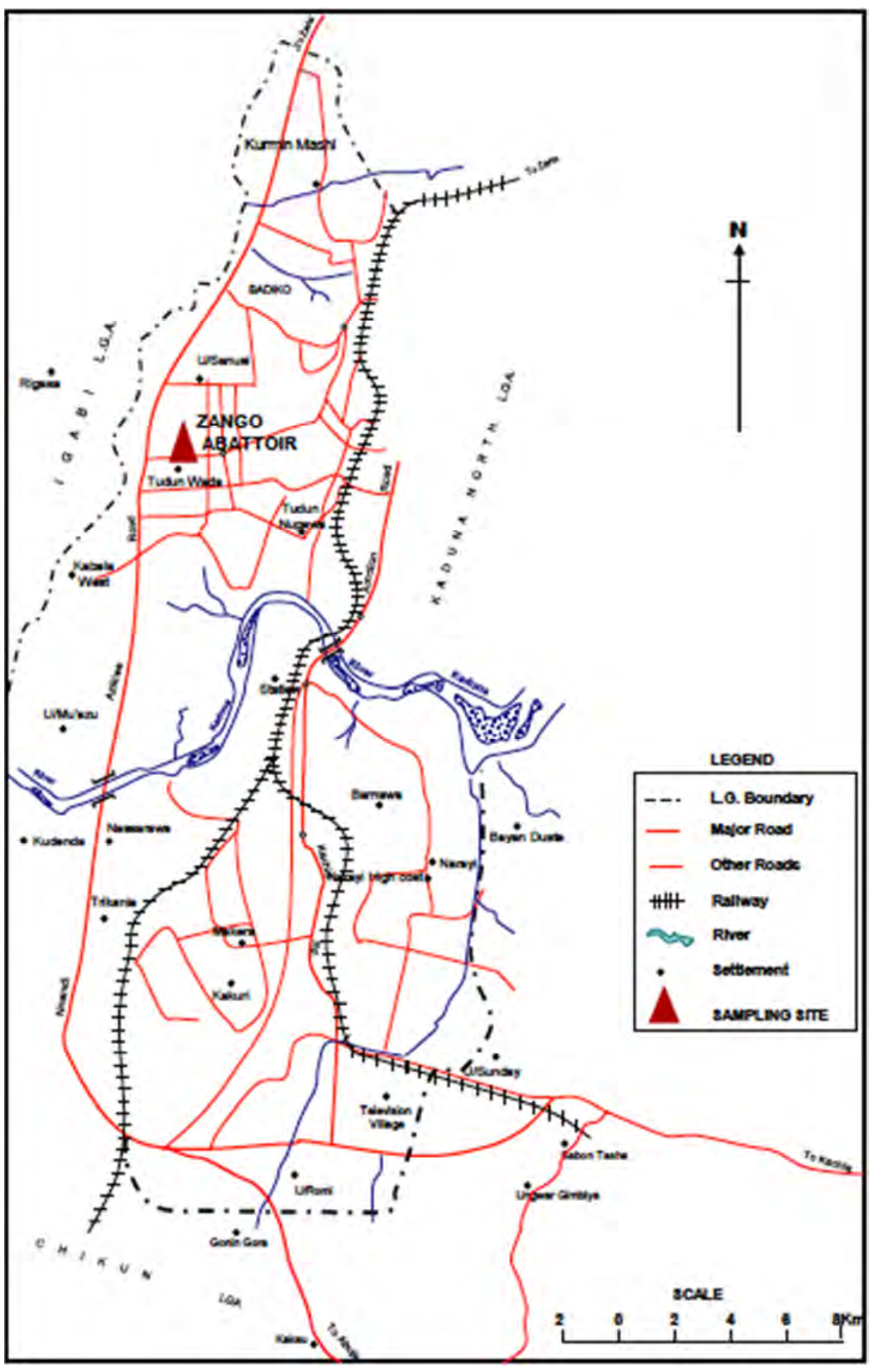

Source: Geography Department, NDA, 2016

Figure 1. Map of Study Area. 
Leaves and stems of the plant samples were rinsed after collection with tap water followed by distilled water so as to remove adhering dirt, and air-dried at room temperature. Samples were chopped up and sieved using $2 \mathrm{~mm}$ mesh. The sieved samples were then kept in a plastic container, labeled and stored at room temperature before analysis. $1 \mathrm{~g}$ of the dried powdered sample of each vegetable was weighed into a beaker and $10 \mathrm{~cm}^{3}$ of aqua regia was added and stirred continuously for a few minutes, and then $5 \mathrm{~cm}^{3}$ of distilled water was added to the mixture and stirred again. The resulting solution was filtered into a volumetric flask and made up to the mark using distilled water. The samples were analysed for heavy metal using atomic absorption spectrophotometer.

Data obtained were analyzed using Microsoft Excel 2013 and Minitab 17 software. The data were expressed in terms of descriptive statistics while the figures were presented with Mean values as (Mean $\pm \mathrm{SD}$ ). A p-value less than 0.05 were considered as significant.

\section{Results and Discussions}

Table 1 shows the concentrations of manganese, iron, zinc and copper in $H$. cannabinus and $M$. oleifera. The concentration of manganese in the leaves and stems of $H$. cannabinus were $3.469 \mathrm{mg} / \mathrm{kg}$ and $0.628 \mathrm{mg} / \mathrm{kg}$ respectively while those of $M$. oleifera contained $1.597 \mathrm{mg} / \mathrm{kg}$ and 0.678 $\mathrm{mg} / \mathrm{kg}$. The concentrations of manganese in $H$. cannabinus and $M$. oleifera were statistically significant at $(\mathrm{p}<0.05)$. The values obtained fall below the maximum residue limit of 6.61 $\mathrm{mg} / \mathrm{kg}$ set by WHO/FAO [11].

Table 1. Concentration of $\mathrm{Mn}, \mathrm{Fe}, \mathrm{Zn}$ and $\mathrm{Cu}$ in Hibiscus cannabinus and Moringa oleifera.

\begin{tabular}{lllll}
\hline Samples & Plant Part & Mn (mg/kg) & Fe (mg/kg) & Zn (mg/kg) \\
\hline H. cannabinus & Leaves & $3.469 \pm 0.006$ & $12.757 \pm 0.0011$ & $0.700 \pm 0.0002$ \\
H cannabinus & Stem & $0.628 \pm 0.0006$ & $13.618 \pm 0.004$ & $0.901 \pm 0.0035$ \\
M. Oleifera & Leaves & $1.597 \pm 0.0091$ & $29.293 \pm 0.0026$ & $10.774 \pm 0.0026$ \\
M. oleifera & Stem & $0.678 \pm 0.0011$ & $8.362 \pm 0.0006$ & $0.071 \pm 0.0002$ \\
\hline
\end{tabular}

The highest concentration of iron $(29.293 \mathrm{mg} / \mathrm{kg})$ was recorded in the leaves of $M$. oleifera. Other values obtained were $8.362,12.757$ and $13.618 \mathrm{mg} / \mathrm{kg}$ in the stem of $M$. oleifera, leaves and stems of $H$. cannabinus respectively. The concentrations of iron in $H$. cannabinus and M. oleifera samples were statistically significant at $(\mathrm{p}<0.05)$. Osu and Okereke reported the concentrations of iron ranging from 5.45 to $14.5 \mathrm{mg} / \mathrm{kg}$ in edible crops grown at Umuahia abattoir which agrees with findings in this study [10]. However, Opaluwa et al., reported values ranging from 0.20 to 0.34 $\mathrm{mg} / \mathrm{kg}$ in crops grown around dumpsite in Lafia metropolis [12]. The results obtained in this study fall below the maximum residue guidelines limit $(48.0 \mathrm{mg} / \mathrm{kg})$ set by WHO/FAO [11].

The highest concentration of zinc was recorded in the leaves of $M$. oleifera $(10.774 \mathrm{mg} / \mathrm{kg})$ and the lowest was recorded in the leaves of $H$. Cannabinus $(0.007 \mathrm{mg} / \mathrm{kg})$. Other values obtained were $0.901 \mathrm{mg} / \mathrm{kg}$ and $5.874 \mathrm{mg} / \mathrm{kg}$ for the stems of $H$. Cannabinus and $M$. oleifera respectively. The concentrations of zinc in $H$. cannabinus and M. oleifera were statistically significant at $(\mathrm{p}<0.05)$. Similarly, Opaluwa et al., reported values ranging from 0.02 to $0.04 \mathrm{mg} / \mathrm{kg}$ in edible vegetables grown at a dumpsite in Lafia metropolis [12]. These values obtained are below the maximum residue limit of $60.0 \mathrm{mg} / \mathrm{kg}$ and $50.0 \mathrm{mg} / \mathrm{kg}$ set by WHO/FAO and NAFDAC respectively $[11,12]$.

The concentration of copper in the leaves and stem of $M$. oleifera were $0.223 \mathrm{mg} / \mathrm{kg}$ and $0.087 \mathrm{mg} / \mathrm{kg}$ respectively. Concentration of $0.155 \mathrm{mg} / \mathrm{kg}$ was found in the leaves of $H$. cannabinus while $0.071 \mathrm{mg} / \mathrm{kg}$ was found in its stem. The concentrations of copper in H. cannabinus and M. oleifera were statistically significant at $(\mathrm{p}<0.05)$. Osu and Odoemelam reported concentration of copper in M. oleifera and $H$. cannabinus cultivated at an abattoir in Port-Harcout metropolis to be $8.600 \mathrm{mg} / \mathrm{kg}$ and $11.010 \mathrm{mg} / \mathrm{kg}$ respectively which is much higher than findings in this study [13]. The values obtained in this study are within the limit $(40.0 \mathrm{mg} / \mathrm{kg}$ and $20.0 \mathrm{mg} / \mathrm{kg}$ ) set by WHO/FAO and NAFDAC $[11,12]$.

Table 2 shows the concentrations of nickel, cadmium, chromium, lead and cobalt in H. cannabinus and M. oleifera. The concentration of nickel in the leaves and stem of $M$. oleifera were $0.044 \mathrm{mg} / \mathrm{kg}$ and $0.020 \mathrm{mg} / \mathrm{kg}$ respectively. Concentration of $0.031 \mathrm{mg} / \mathrm{kg}$ was found in the leaves of $H$. cannabinus while $0.025 \mathrm{mg} / \mathrm{kg}$ was found in its stem. The concentrations of nickel in $H$. cannabinus and M. oleifera were statistically significant at $(\mathrm{p}<0.05)$. Opaluwa et al., (2012) reported similar results in edible crops grown within Lafia dumpsites with values ranging from $0.00-0.04 \mathrm{mg} / \mathrm{kg}$ [12]

Table 2. Concentration of $\mathrm{Ni}, \mathrm{Cd}, \mathrm{Cr}, \mathrm{Pb}$ and $\mathrm{Co}$ in Hibiscus cannabinus and Moringa oleifera.

\begin{tabular}{|c|c|c|c|c|c|c|}
\hline Samples & Plant Part & Ni (mg/kg) & $\mathrm{Cd}(\mathrm{mg} / \mathrm{kg})$ & $\mathrm{Cr}$ (mg/kg) & $\mathrm{Pb}$ (mg/kg) & Co (mg/kg) \\
\hline H. cannabinus & Leaves & $0.031 \pm 0.0006$ & $0.039 \pm 0.0001$ & $0.017 \pm 0.0010$ & $1.144 \pm 0.0008$ & $0.125 \pm 0.0005$ \\
\hline H cannabinus & Stem & $0.025 \pm 0.0007$ & $0.020 \pm 0.0006$ & $0.151 \pm 0.0005$ & $1.092 \pm 0.0003$ & $0.115 \pm 0.0010$ \\
\hline M. Oleifera & Leaves & $0.044 \pm 0.0002$ & $0.017 \pm 0.0001$ & $0.184 \pm 0.0004$ & $1.213 \pm 0.0002$ & $0.201 \pm 0.0016$ \\
\hline
\end{tabular}

The concentration of cadmium in the leaves and stem of $H$ cannabinus were $0.039 \mathrm{mg} / \mathrm{kg}$ and $0.020 \mathrm{mg} / \mathrm{kg}$ respectively as shown in Table 2. Concentration of $0.017 \mathrm{mg} / \mathrm{kg}$ was found in the leaves of $M$. oleifera while $0.018 \mathrm{mg} / \mathrm{kg}$ was 
found in its stem. The concentrations obtained were statistically significant at $(\mathrm{p}<0.05)$. These values obtained are within the maximum residue limit $(0.2 \mathrm{mg} / \mathrm{kg})$ set by WHO/FAO [11]. Osu and Odoemelam reported concentrations of cadmium in $H$. cannabinus and $M$. oleiferas cultivated at an abattoir in Port-Harcourt metropolis to be $0.300 \mathrm{mg} / \mathrm{kg}$ and $0.910 \mathrm{mg} / \mathrm{kg}$ respectively which is higher than findings in this study as well as WHO/FAO [13].

The concentration of chromium in the leaves of $M$. oleifera was $0.184 \mathrm{mg} / \mathrm{kg}$. However, it was not detected in its stem. Concentration of $0.017 \mathrm{mg} / \mathrm{kg}$ was found in the leaves of $H$. cannabinus while its stems recorded $0.125 \mathrm{mg} / \mathrm{kg}$. The concentrations of chromium in the vegetables were statistically significant at $(\mathrm{p}<0.05)$. These values obtained are within the maximum residue limit $(2.30 \mathrm{mg} / \mathrm{kg})$ set by WHO/FAO [11].

The concentration of lead in the leaves and stem of $M$. oleifera were $1.213 \mathrm{mg} / \mathrm{kg}$ and $1.167 \mathrm{mg} / \mathrm{kg}$ respectively. Other values obtained were $1.144 \mathrm{mg} / \mathrm{kg}$ and $1.092 \mathrm{mg} / \mathrm{kg}$ for the leaves and stems of $H$. cannabinus respectively. The concentrations of lead in $H$. cannabinus and M. oleifera were statistically significant at $(\mathrm{p}<0.05)$. Much lower results were obtained by Osu and Odoemelam where the concentration of lead reported in $M$. oleifera and $H$. cannabinus grown at an abattoir in Port-Harcourt metropolis were $0.100 \mathrm{mg} / \mathrm{kg}$ and $0.030 \mathrm{mg} / \mathrm{kg}$ respectively [13]. The values obtained in this study were above the maximum residue limit $0.3 \mathrm{mg} / \mathrm{kg}$ set by WHO/FAO but below the limit set by NAFDAC $[11,12]$.

The concentrations of cobalt in the leaves and stems of $H$. cannabinus were $0.125 \mathrm{mg} / \mathrm{kg}$ and $0.115 \mathrm{mg} / \mathrm{kg}$ respectively. Concentration of $0.201 \mathrm{mg} / \mathrm{kg}$ was found in the leaves $M$. oleifera while $0.190 \mathrm{mg} / \mathrm{kg}$ was found in its stem. The concentrations of cobalt in $H$. cannabinus and M. oleifera were statistically significant at $(\mathrm{p}<0.05)$. Opaluwa et al., however reported values ranging from 0.07 to $0.43 \mathrm{mg} / \mathrm{kg}$ in various edible crops cultivated at a dumpsite in Lafia metropolis which is in agreement with findings in this study [12].

Arsenic was not detected in H. cannabinus and M. oleifera analysed. This could mean that there is low pollution with respect to arsenic in the study area. The maximum residue limit for arsenic is $0.43 \mathrm{mg} / \mathrm{kg}$ as set by WHO/FAO [11].

\section{Conclusions}

This study indicates that concentration of iron, zinc and lead were below the maximum tolerable level recommended by the Joint FAO/WHO Expert. Other metals such as manganese, copper, nickel, cadmium, chromium and cobalt were also present but in trace amounts. Arsenic was however not detected in all the vegetables, indicating that there is low pollution with respect to arsenic in the study area. These results point to the fact that the activities in and around the abattoir are contributing to the loading of heavy metals and also increases the organic matter in the soils through the abattoir effluents. People consuming vegetables grown at the Tudun Wada abattoir, consume trace amount of these metals: iron, zinc and lead. Consumption of these metals could lead to bio accumulation in human organs such as the kidney, lungs, liver and intestine causing severe damage to the body.

\section{References}

[1] Adesemoye AO, Opere BO, Makinde SC. Microbial Content of abattoir waste water and its contaminated soil in Lagos, Nigeria. African Journal of Biotechnology, 2006; 5 (20): 1963-1968.

[2] Hornby AS. Oxford Advanced Learner's Dictionary of current English, Oxford University Press. 2006; 7th ed. p. 1381.

[3] Katarzyna RA, Monkiewicz J, Andrzej, G. Lead, cadmium, arsenic, copper and zinc contents in hair of cattle living in the area contaminated by a copper smelter. Bull Vet Inst Pulawy, 2009; 53: 703-706.

[4] Odoemelan SA, Ajunwa, O. Heavy Metal Status and Physicochemical Properties of Agricultural Soil amended by short term application of animal manure. Journal of Chemical Society of Nigeria, 2008; 30: 60-63.

[5] Fadeyibi, A, Halilu A, Osunde ZD. Analysis of Physicochemical Properties of Abattoir Wastewater for Irrigation in Minna, Niger State. Continental J. Water, Air and Soil Pollution, 2011; 2 (2): 12-15.

[6] Osu CI, Ogoko EC, Emeziem D. Metal Species, Mobility and Bioavailability In An Oil Impacted Soil From Ikoku And Alaoji Automobile Spare Parts Markets, Niger-Delta Nigeria. American Academic \& Scholarly Research Journal, 2014; 6 (3): 123-127.

[7] Sajjad K, Robina F, Shagufta S, Mohammed A, Maria S. Health Risk Assessment of Heavy Metals for Population via Consumption of Vegetables. World Applied Sciences Journal, 2009; 6 (12): 1602-1606.

[8] Cui YJ, Zhu YG, Zhai R, Huang Y, Qiu Y, Liang J. Exposure to metal mixtures and human health impacts in a contaminated area in Nanning, China. Environment International, 2005; 31: 784-790.

[9] Osu CI, Ogoko EC. Bioconcentration and Transfer of Heavy Metal from Soil into Verninia amydalina, Telfera occidendalis and Amarathus spinosustatio. Journal of Applied Phytotechnology in Environmental Sanitation, 2014; 3 (4): 117-121.

[10] Osu CI, Okereke VC. Heavy metal accumulation from abattoir wastes on soils and some edible vegetables in selected areas in Umuahia metropolis. Int. J. Curr. Microbiol. App. Sci., 2015; 4 (6): 1127-1132.

[11] FAO/WHO. Food additives and contaminants, Joint Codex Alimentarius Commission, FAO/WHO. Food standards Programme, ALINORM 01/12A. 2001.

[12] Opaluwa OD, Aremu MO, Ogbo LO, Abiola, KA, Nweze, NO. Heavy metal concentrations in soils, plant leaves and crops grown around dump sites in Lafia Metropolis, Nasarawa State, Nigeria. Advances in Applied Science Research, 2012; 3 (2): 780-784.

[13] Osu CI, Odoemelam SA. Availability of Toxic Metals and Its Transfer from Soil to Some Selected Edible Vegetables Consumed in Port Harcourt City, Nigeria. J. Agric. Food. Tech., 2015; 5 (1): 1-4. 